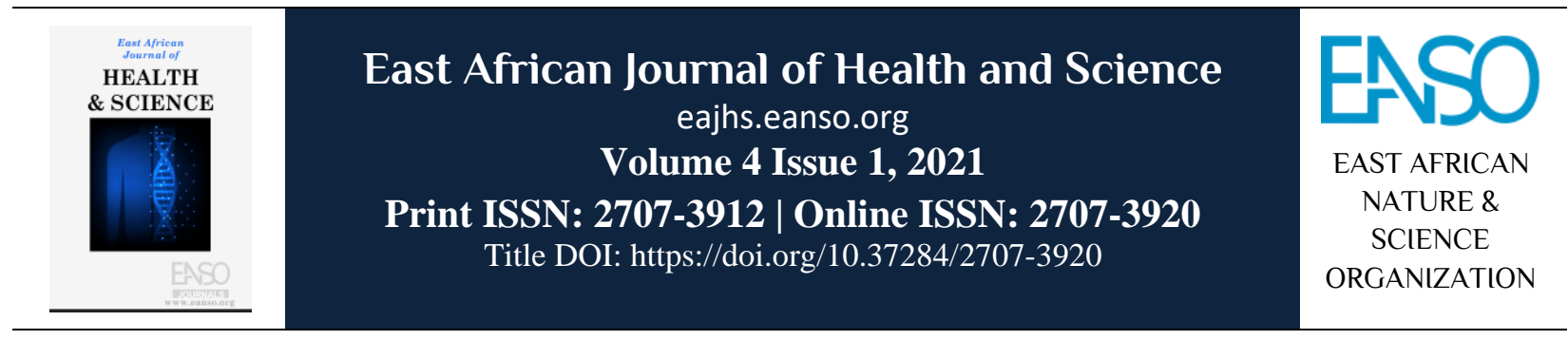

Original Article

\title{
Microbial and Physicochemical Qualities of Septic Tank Wastewater: An Evaluation.
}

\author{
Dr. Ifeanyi Mirian Oyem, $P h D^{1 *}$, Dr. Hector Henry Oyem, $P h D^{1} \&$ Dr. Emmanuel Esosa \\ Imarhiagbe, $P h D^{2}$ \\ ${ }^{1}$ University of Delta, Agbor, PMB 2090, Delta State, Nigeria. \\ ${ }^{2}$ University of Benin, PMB. 1154, Ugbowo, Benin City, Nigeria. \\ *Author for correspondence ORCID ID: 000000025883 5030; email: ifyoyem2011@yahoo.com.
}

Article DOI: https://doi.org/10.37284/eajhs.4.1.469

\section{Date Published: ABSTRACT}

10 November 2021 The physicochemical and microbial qualities of septic tank effluent samples from households within the study area were evaluated. Three replicate

Keywords: samples from Locations A, B, and C representing Agbor, Benin City, and Sapele regions of Delta and Edo States, Nigeria were collected from both

Septic Tank,

Raw Sewage,

Semi-Treated Sewage,

Physicochemical,

Microbial Qualities. the inlet tank (raw sewage) and the outlet chamber (semi-treated sewage) for physicochemical and microbiological analyses using standard methods. Results of the physicochemical analyses showed that $\mathrm{pH}$ values ranged from $6.5-7.7$ across locations and in both the raw and semi-treated samples. Electrical conductivity (EC), Total suspended solid (TSS) and BOD was significantly higher ( $p>0.05)$ in the raw sewage (RS) than in the semi-treated (SS), while DO was higher $(\mathrm{p}>0.05)$ in the SS in all three locations sampled. Microbial analysis shows that total heterotrophic bacteria (THB) was highest in the RS in two locations. Microbial isolates from wastewater samples included Staphylococcus aureus, Proteus mirabilis, Escherichia coli, Pseudomonas aeruginosa, and Aspergillus niger. DO was low at an average of 3.20 and $3.73 \mathrm{mg} / \mathrm{L}$ in both chambers of the septic tank. Average $\mathrm{BOD}_{5}$ of 59.4 and $42.8 \mathrm{mg} / \mathrm{L}$ and COD average of 206.8 and $153.2 \mathrm{mg} / \mathrm{L}$ were reported for the RS and SS chambers. 0.3 was the value of the ratio of $\mathrm{BOD}_{5} / \mathrm{COD}$ for the RS and SS in the study. This infers that biodegradation was slow and inefficient in the septic tank system, and that modification of the design is recommended to increase retention time in the RS chamber.

41 This work is licensed under a Creative Commons Attribution 4.0 International License. 


\section{APA CITATION}

Oyem, I. M., Oyem, H. H. \& Imarhiagbe, E. E. (2021). Microbial and Physicochemical Qualities of Septic Tank Wastewater: An Evaluation. East African Journal of Health and Science, 4(1), 41-60. https://doi.org/10.37284/eajhs.4.1.469.

\section{CHICAGO CITATION}

Oyem, Ifeanyi Mirian, Hector Henry Oyem, \& Emmanuel Esosa Imarhiagbe. 2021. "Microbial and Physicochemical Qualities of Septic Tank Wastewater: An Evaluation.". East African Journal of Health and Science 4 (1), 41-60. https://doi.org/10.37284/eajhs.4.1.469.

\section{HARVARD CITATION}

Oyem, I. M., Oyem, H. H., \& Imarhiagbe, E. E. (2021) "Microbial and Physicochemical Qualities of Septic Tank Wastewater: An Evaluation.”, East African Journal of Health and Science, 4(1), pp. 41-60. doi: 10.37284/eajhs.4.1.469.

\section{IEEE CITATION}

I. M. Oyem, H. H. Oyem, \& E. E. Imarhiagbe, "Microbial and Physicochemical Qualities of Septic Tank Wastewater: An Evaluation.”, EAJHS, vol. 4, no. 1, pp. 41-60, Nov. 2021.

\section{MLA CITATION}

Oyem, Ifeanyi Mirian, Hector Henry Oyem, \& Emmanuel Esosa Imarhiagbe. "Microbial and Physicochemical Qualities of Septic Tank Wastewater: An Evaluation.”. East African Journal of Health and Science, Vol. 4, no. 1, Nov. 2021, pp. 41-60, doi:10.37284/eajhs.4.1.469.

\section{INTRODUCTION}

Sewage, which is liquid waste, is the wastewater of a community. It is a combination of water-borne wastes from homes, businesses, health institutions, and industries (Angeli et al., 2018). Wastewater emanating from sundry human activities may carry pathogenic organisms that can transmit diseases to humans and other animals. It also contains organic matter that can cause odour and nuisance problems, hold nutrients that may cause eutrophication of receiving water bodies, and can lead to toxicological problems (Doelle, 2001).

For reasons of public health and conservation, man has been forced to develop methods of wastewater storage and treatment which results in the mineralization of the organic components of wastewater prior to its discharge into the natural environment. This is usually achieved by an adequate public or community sewerage system. This sewerage system is not quite feasible in developing and under-developed nations of the world (Rojer, 2002). Hence, individual household sewage disposal system often referred to as septic tank system is the most commonly used domestic wastewater disposal method in Nigeria (Fidelia, 2004).

A septic tank system is an enclosed receptacle designed to collect wastewater, segregate settleable and floatable solids, accumulate and digest organic matter and discharge partially treated effluent. The most widely accepted type is the gravity-fed (made of sandcrete block) used by over $40 \%$ of people around the world (Fidelia, 2004). This consists of a septic tank where the ultimate sewage treatment in terms of organic matter removal is accomplished (Robert and Terry, 2004). The septic tank acts largely as a settling tank, within which the organic components of the wastewater undergo anaerobic digestion (Meegoda et al., 2018).

Effluent from the septic tanks is as dangerous as raw sewage contains pollutants concentrations higher than both locally and internationally acceptable limits (Burubai, 2005). Therefore, effluent from a septic tank is further directed to a soak away pit before disposal. This final treatment and disposal of domestic wastewater are historically done in the soil which serves as a universal filter.

Septic tank sewage system pervades every nook and cranny of the world. It is the method of choice in domestic sewage disposal especially in urban areas of Nigeria, accounting for $90-95 \%$ of the application. Despite its wide usage, little is known about this sewage disposal system. Notably, literature is scanty on the microbial ecology and dynamics of the system, on the other hand, the physicochemical parameters are also not well reported. To this end, this exercise is a detailed study of the physicochemical characteristics of septic tank effluents in relation to the microbial 
communities, and to ascertain how the interdependency of these factors affect the workings of the septic tank system.

\section{MATERIALS AND METHODS}

\section{Sample Area}

Sewage effluent samples were collected from different septic tanks within three locations in Edo/ Delta States; Agbor (Location A), Benin (Location B), and Sapele (Location C) in the South region of
Nigeria (Figure 1). This made up the study area. The climate of the study area is characteristics of a subequatorial climate with an annual average air temperature of $27-29^{\circ} \mathrm{C}$ (Odjugo, 2008; Oyem et al., 2014). Rainfall pattern is characteristic of the monsoon with a mean annual rainfall of 2,255 mm, and annual humidity of $81 \%$; soil types are mostly red-yellow ferralsols (Avwunudiogba, 2000; Oyem et al., 2014; Oyem et al., 2015), apart from Sapele which has the yellow-white soil characteristic of the Delta region.

Figure 1: Study area showing locations A, B and C

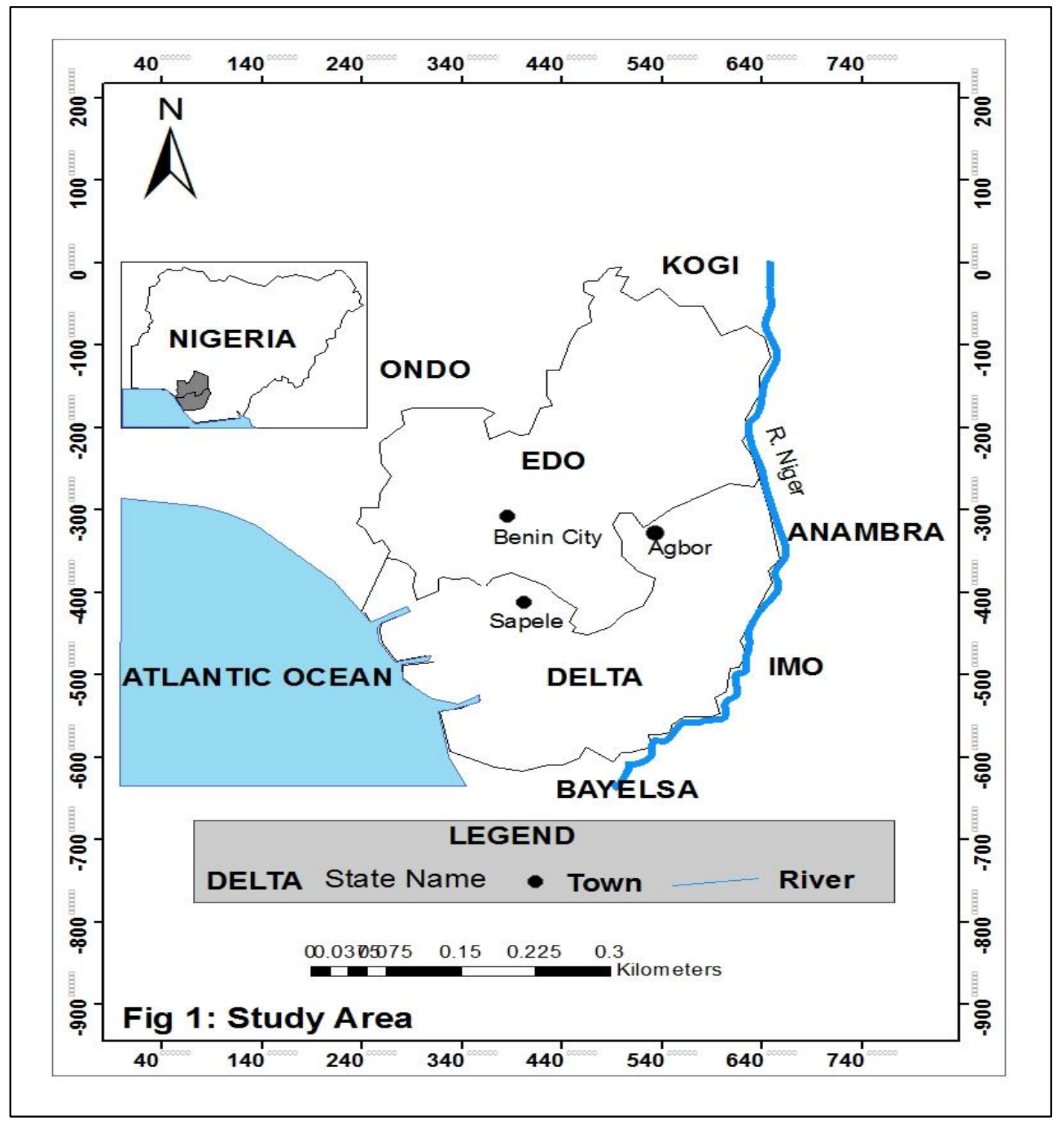




\section{Sample Collection}

Samples were collected in November/December 2018 and January 2019 respectively in the middle of the harmattan (dry) season (November - March) with temperatures ranging between $21-36{ }^{\circ} \mathrm{C}$ (Abdusalam, 2015; Ogunrayi et al., 2016; Eresanya et al., 2018) and percentage occurrence of warm days with maximum temperature above $34{ }^{\circ} \mathrm{C}$ representing the $90^{\text {th }}$ percentile value (Ogunrayi et al., 2016).

An average of 3 septic tanks were sampled per sample area; in all, a total of 10 was sampled in all (4 were sampled in location B). Many residents were averse to their septic tanks being broken into even though we had masons accompanying us to immediately seal up the sewage digesters after sampling.

Sampling was done in the mornings usually before noon using sterile $1 \mathrm{~L}$ plastic bottles and $200 \mathrm{ml}$ dark glass bottles attached to a $1 \mathrm{~m}$ length stick to collect samples just below the sewage surface from the inlet (raw) and outlet (semi-treated) chambers respectively. Samples were covered air-tight, stored in ice packs (at $4 \pm 2{ }^{\circ} \mathrm{C}$ ), and transferred to the laboratory for analyses.

The septic tanks from the various sample areas (locations) now designated as $\mathrm{A}, \mathrm{B}$, and $\mathrm{C}$ representing Agbor, Benin, and Sapele respectively were chosen for their similarity in size and content. The only difference being the number of persons served and the lifestyle of the users. An average of $5-6$ persons per household was recorded for locations $\mathrm{A}$ and $\mathrm{C}$, whereas Location $\mathrm{B}$ had an average of $7-8$ persons per household. Inhabitants of these areas comprise civil servants and owners of small-scale sundry businesses in location A. Those in location B included civil servants, corporate business owners, and traders. Meanwhile, the inhabitants of location $\mathrm{C}$ were essentially commercial business owners and traders.

Apart from the holiday period when schools have closed for the session, households are virtually empty between the hours of 9.00 am to $6.00 \mathrm{pm}$ as children were in school and adults were away at work and business centres. In all cases, samples were collected in the morning between the hours of 9-12 pm during the schools' session. Samples were collected in triplicates according to the standard methods for the examination of water and wastewater by the American Public Health Association (APHA, 1995).

At the laboratory, composite samples were made in the $1 \mathrm{~L}$ bottles for the raw and semi-treated samples respectively according to the sample area. Each of these raw and semi-treated sewage samples was then analyzed for the parameters being studied.

Soil collection from the sample areas was done using a hand auger (model 25030) with a width of $1.6 \mathrm{~cm}$ and depth of $33 \mathrm{~cm}$ to collect soil within 10$20 \mathrm{~cm}$ depth. The soil obtained in triplicates was placed in a small plastic bag and taken immediately for textural analysis.

\section{Examination of Physicochemical Parameters}

\section{pH Determination}

$1 \mathrm{~mL}$ each of the raw and semi-treated sewage were withdrawn from the composite samples of each of the sample areas using a sterilized $10 \mathrm{~mL}$ measuring cylinder and serially diluted to a final volume of $1,000 \mathrm{~mL}$ (a dilution factor of $10^{3}$ ) with deionized water (Ademoroti, 1996a). Hydrogen ion $\left[\mathrm{H}^{+}\right]$ concentration $(\mathrm{pH})$ was determined using a Hanna Multi-Parameter Metre Type HI 9828 earlier standardized.

\section{Electrical Conductivity}

Aliquots of the serially diluted samples were likewise taken to determine the electrical conductivity (EC) using the $\mathrm{HACH}$ conductivity meter. The metre probe was dipped into the samples and left for about 3 mins for equilibration before the readings were taken and recorded. Electrical conductivity values were reported in $\mu \mathrm{S} / \mathrm{cm}$.

\section{Total suspended solids}

Total Suspended Solids (TSS) was determined using a membrane filter paper (Whatman No.1) in accordance with standard methods APHA 2540D (APHA, 1995) of the American Public Health Association. 


\section{Dissolved oxygen (DO)}

Dissolved oxygen (DO) measurements were obtained by adopting the iodometric (Winkler) method APHA 4500-0-B also of the American Public Health Association (APHA, 1995). DO values were reported in $\mathrm{mg} / \mathrm{L}$.

\section{Biological oxygen demand (BOD)}

The biological oxygen demand $\left(\mathrm{BOD}_{5}\right)$ procedure was based on DO concentration and required an accurate DO determination. BOD measures the amount of oxygen consumed by bacteria from the decomposition of organic matter before and after incubation in the dark at a standard temperature of $20{ }^{\circ} \mathrm{C}$ for a period of 5 days. $100 \mathrm{ml}$ of the sample containing $2 \%$ raw sample to which acidified potassium iodide has been added was titrated against a solution of sodium thiosulphate using 1-2 $\mathrm{ml}$ starch solution as indicator until a colourless solution is obtained (Ademoroti, 1996a; Pepper and Gerba, 2004). The general equation for the determination of $\mathrm{BOD}_{5}$ value is given:

$$
B O D 5(m g / L)=(D 01-D O 5) / P
$$

where: $\mathrm{DO}_{1}=$ initial $\mathrm{DO}$ of the sample

$\mathrm{DO}_{5}=$ Final DO of the sample after 5 days, and

$\mathrm{P}=$ Decimal volumetric fraction of sample used (percent dilution)

- (Ademoroti, 1996a; Pepper and Gerba, 2004)

\section{Chemical Oxygen Demand (COD)}

Chemical oxygen demand (COD) measures the amount of oxygen consumed for the oxidation of total organic matter. The ASTM D 1252, APHA 508 dichromate method was used in the determination of COD (ASTM, 1995).

\section{Determination of Other Physicochemical Parameters}

\section{Colour}

This was determined using Spectronic $20 \mathrm{D}^{+}$ Spectrophotometer and a filter system D 1209 Method (ASTM, 1995). Readings were taken at 455 $\mathrm{nm}$ for both cuvettes (water blank and wastewater samples). The Colour of wastewater was reported in $\mathrm{mg} / \mathrm{L}$.

$$
\text { Pt.Co }=\text { sample colour }- \text { water colour }
$$

\section{Turbidity}

This was measured using the HACH Turbidimeter. Readings were taken at $450 \mathrm{~nm}$ using Spectronic $20 \mathrm{D}^{+}$spectrophotometer for both cuvettes; blank (water) and sample (wastewater).

$$
\text { Turbidity }(N T U)=
$$

instrument reading $\times$ slope reciprocal

\section{Salinity}

This was determined using a Hanna multi-parameter metre type HI 9828. The instrument was powered on, allowed to stand for 20 minutes, and calibrated by pressing SAL mode and immersing the probe in potassium chloride standard solution with a salinity of $3.50 \mathrm{ppt}$. The probe was removed and rinsed with distilled water before dipping into the sample, allowed to stabilize, and reading taken and recorded.

\section{Sulphate}

Determination of sulphate was done using the turbimetric-colorimetric method (Ademoroti, 1996a.). Turbidity was read at $420 \mathrm{~nm}$ in a spectrophotometer (Spectronic 20D ${ }^{+}$). Ammonium Nitrogen was determined using the US EPA (2002) method 350.1. Sample readings were taken colorimetrically at $636 \mathrm{~nm}$ against the part per million (ppm) as blank. Nitrate determinations were done using Brucine colorimetric method. Samples were read spectrophotometrically using Spectronic model $20 \mathrm{D}^{+}$at $470 \mathrm{~nm}$.

\section{Phosphorus}

Determination of phosphorus was done using the ascorbic acid reduction colorimetric method APHA 425C (APHA, 1992). The sample was read spectrophotometrically (Spectronic model $20 \mathrm{D}^{+}$) at $660 \mathrm{~nm}$.

\section{Microbial Analyses of Septic Tank Effluent}

Samples for microbial analysis from the different septic tanks were analysed in the laboratory. 
Isolation, enumeration, identification, and characterization of isolates were done using standard microbiological techniques. Denaturing gradient gel electrophoresis (DGGE) was also used to fingerprint microorganisms in the septic tanks and results were already published in a separate paper (Oyem et al., 2020).

\section{Total Heterotrophic Bacteria (THB)}

This was determined using nutrient media. It was performed in triplicates by plating out $1 \mathrm{~mL}$ aliquot of sewage sample dilution factors of $10^{-4}, 10^{-5}$, and $10^{-6}$ into already sterilized plates and molten nutrient agar was poured into plates containing the samples and shaken properly for adequate mixing of the sample and the agar medium. Plates were then incubated at $37{ }^{\circ} \mathrm{C}$ for $24 \mathrm{hrs}$ (ASTM, 1995; Ademoroti, 1996a; Pepper and Gerba, 2004). After this period, the bacterial colonies on each of the plates were counted and recorded. Identification of isolates was based on cultural characteristics and biochemical testing.

\section{Total Coliform Bacteria (TCB)}

The total coliform bacteria counts were determined using the Most Probable Number (MPN) technique with Mac Conkey broth containing bromocresol purple indicator (ASTM, 1995). The tubes were incubated at $37{ }^{\circ} \mathrm{C}$ for $48 \mathrm{hr}$ for subsequent isolation and identification of coliform.

\section{Total Fungal Count (TFC)}

This was performed in triplicates by plating out 0.1 $\mathrm{ml}$ aliquots of sewage sample dilutions: $10^{-4}, 10^{-5}$, and $10^{-6}$ on potato dextrose agar plates containing streptomycin. The culture plates were incubated at room temperature for $72 \mathrm{hr}$. Distinct hyphae were transferred to sterile plates of malt extract agar and incubated at room temperature for $72 \mathrm{hr}$. The pure culture was transferred to sterile malt extract slants in McCartney bottles and stored in the refrigerator at $4{ }^{\circ} \mathrm{C}$. Identification was based on microscopic and macroscopic examination.

\section{Soil Analysis of Study Area}

The soil from the different locations was analysed using the hydrometer method. The soil hydrometer was lowered into the cylinder containing the soil mixture at different times. Forty-five seconds to measure sand content, one and a half hours to measure the silt content, and twelve hours to measure clay content. The number on the hydrometer that is visible (above the soil solution) is recorded. A blank is used to calibrate the hydrometer. The values recorded from the readings are used to calculate the percent clay, silt, and sand. The blank is subtracted from each of the three readings. The calculations are as follows:

$$
\begin{aligned}
\text { Per cent silt }= & (\text { dried mass of soil sand hydrometer reading }- \text { blank reading }) \\
& / \text { dried mass of soil } \times 100
\end{aligned}
$$

Per cent clay $=($ clay hydrometer reading - blank reading $) /($ dried mass of soil $) \times 100$

$$
\text { Per cent }=100-(\text { per cent clay }+ \text { per cent silt })
$$




\section{RESULTS AND DISCUSSION}

\section{Physicochemical Qualities of Septic Tank Sewage $p H$}

Figure 2: pH characteristics of effluent from raw sewage (RS) and semi-treated sewage (SS) at the different study locations.

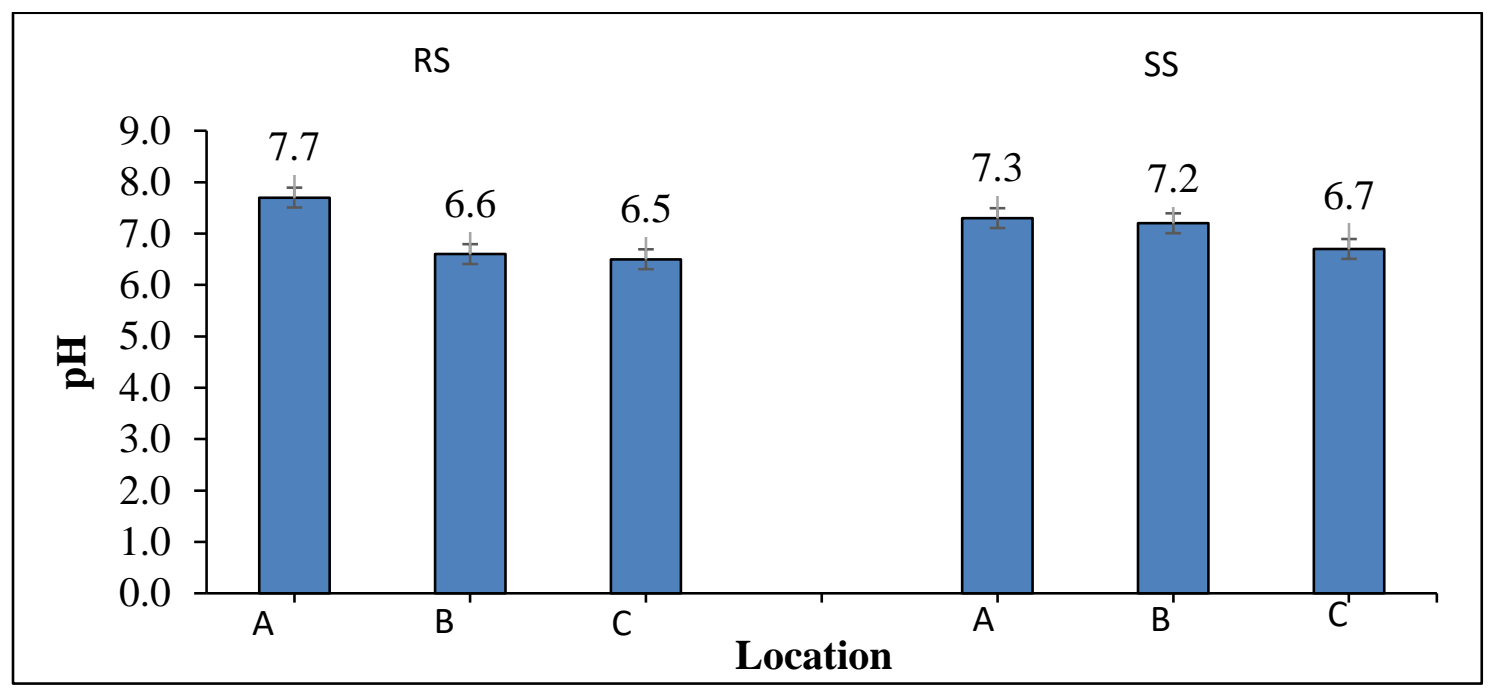

Results in Figure 2 show that effluent samples from all three sample areas had $\mathrm{pH}$ between weakly acidic and weakly alkaline $(6.5 \pm 0.2$ and $7.7 \pm 0.1)$. The average $\mathrm{pH}$ for the study area is 6.93 and 7.06 for both the raw (RS) and semi-treated sewage (SS) respectively, showing that the $\mathrm{RS} \mathrm{pH}$ was slightly more acidic and seeming more adaptable to acidforming bacteria. These average $\mathrm{pH}$ values of 6.93 and 7.06 are close to the normal range of 6.5 and 7.2 reported by (Stuth and Guichard 1989) for residential septic tank effluent. The $\mathrm{pH}$ of the SS was higher in locations B (7.2 \pm 0.2$)$ and C $(6.7 \pm$ $0.2)$ than they were in the RS samples in the same location. These conditions would favour the activities of methanogens in the SS chamber. Location $\mathrm{A}$ had the highest $\mathrm{pH}$ value for both $\mathrm{RS}$ and SS $(7.7 \pm 0.1$ and $7.3 \pm 0.2)$ respectively in all the study areas. Acidophiles thrive better at $\mathrm{pH}<6$, while methane-formers do better at higher $\mathrm{pH}>6$; being inactivated at more acidic $\mathrm{pH}$ (Ademoroti, 1996b). Ademoroti (1996b) states that the ideal $\mathrm{pH}$ condition for anaerobic - methane formation is $\mathrm{pH}$ $>6$.

The presence of dissolved salts and carbonates as well as the mineral composition of the surrounding soil can impact $\mathrm{pH}$ values (Fondriest Environmental Inc., 2013). To protect microorganisms the $\mathrm{pH}$ of wastewater needs to remain within $6.0-9.0$ as microbial activity is inhibited at $\mathrm{pH}$ below 6.0 and above 9.0. To ensure efficient anaerobic digestion in a septic tank, a balance between the acid-forming, hydrogen-forming bacteria and the methaneforming bacteria should be maintained. Acidity is more inhibitory to methane-forming bacteria as previously stated which functions at a $\mathrm{pH}$ range of 6.7 and $7.4 \mathrm{~B}$. This $\mathrm{pH}$ range is similar to those obtained in this present study.

Methane-producing bacteria formed $(53.9 \%)$ of the total species occurring in the wastewater studied (Oyem et al., 2020). Production of organic acids by acid-forming and hydrogen-forming bacteria tends to lower the $\mathrm{pH}$ of the septic tank. Under normal conditions, this $\mathrm{pH}$ reduction is buffered by bicarbonate produced by methane-forming bacteria (Bitton, 1999). Thus, in a stable tank in which there is a balance between the various bacteria that are involved in digestion, $\mathrm{pH}$ should remain close to neutral.

Meanwhile, the result of the analysis of variance (ANOVA) (result not presented here) for $\mathrm{pH}$ values of the raw sewage (RS) across the study area shows that $\mathrm{pH}$ values at the different sample areas varied significantly at 0.05 level of significance. 


\section{Electrical Conductivity $(E C)$}

Figure 3: EC characteristics of effluent from raw sewage (RS) and semi-treated sewage (SS) at the different study locations.

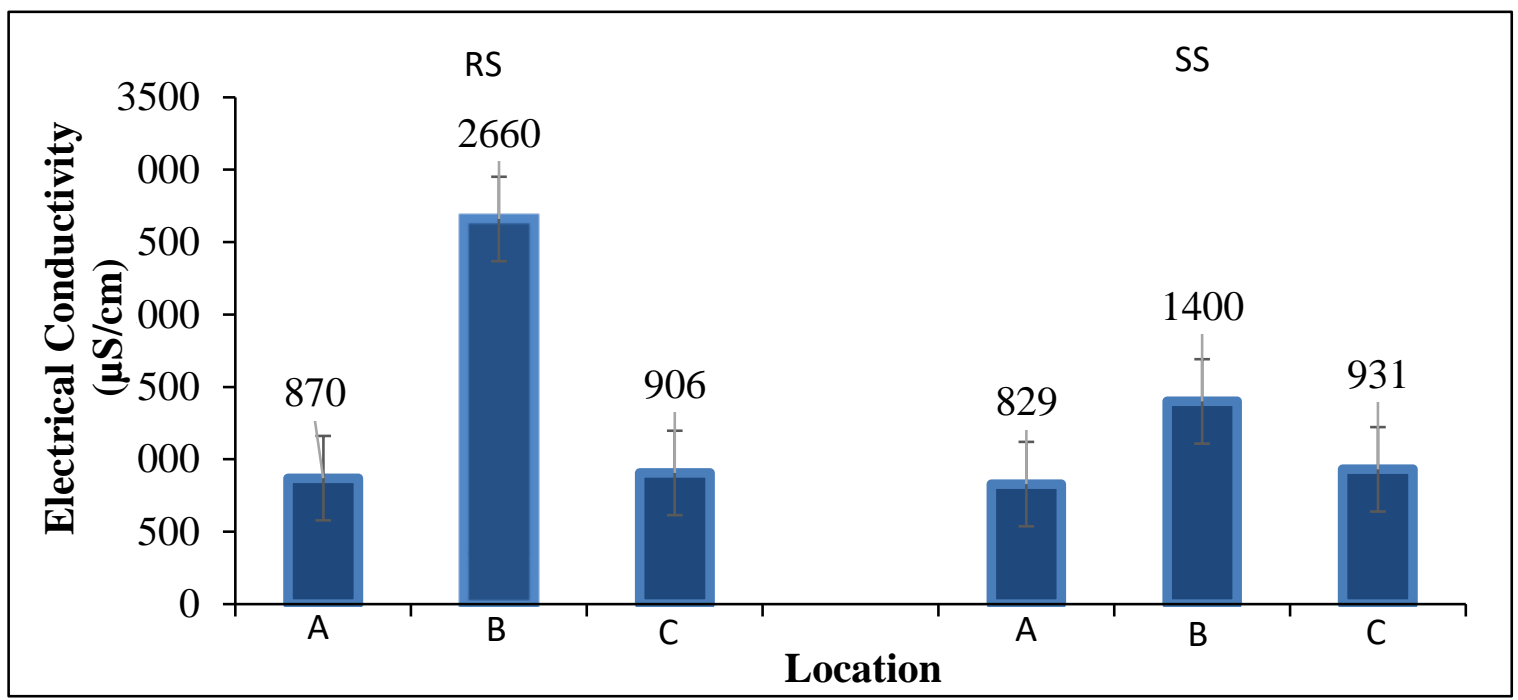

Electrical conductivity (EC) was highest in location B $(2660 \mu \mathrm{S} / \mathrm{cm})$ and lowest in location A $(870$ $\mu \mathrm{S} / \mathrm{cm})$. The mean value of electrical conductivity (EC) in both RS and SS effluent ranged from $829 \pm$ $6.8-2660 \pm 11.0 \mu \mathrm{S} / \mathrm{cm}$ (Figure 3) in the study area. EC gives an idea of the amount of dissolved ions in the effluent (Yilmaz and Koc, 2014). Raw sewage (RS) had higher EC in all three sample areas when compared to the semi-treated sewage (SS), except in location C. Apparently, the SS contained less dissolved solute. EC also gives a picture of the total dissolved solids (TDS) of the system. High values of EC show that inorganic ions such as $\mathrm{H}^{+}$, $\mathrm{Na}^{+}, \mathrm{K}^{+}, \mathrm{Mg}^{2+}, \mathrm{Ca}^{2+}, \mathrm{SO}_{4}{ }^{2-}$ and $\mathrm{HCO}_{3}{ }^{-}$were present in a reasonable concentration in wastewater (Adams, 1990).

Total Suspended Solids (TSS)

Figure 4: Physicochemical characteristics of effluent from raw sewage (RS) at the different study locations.

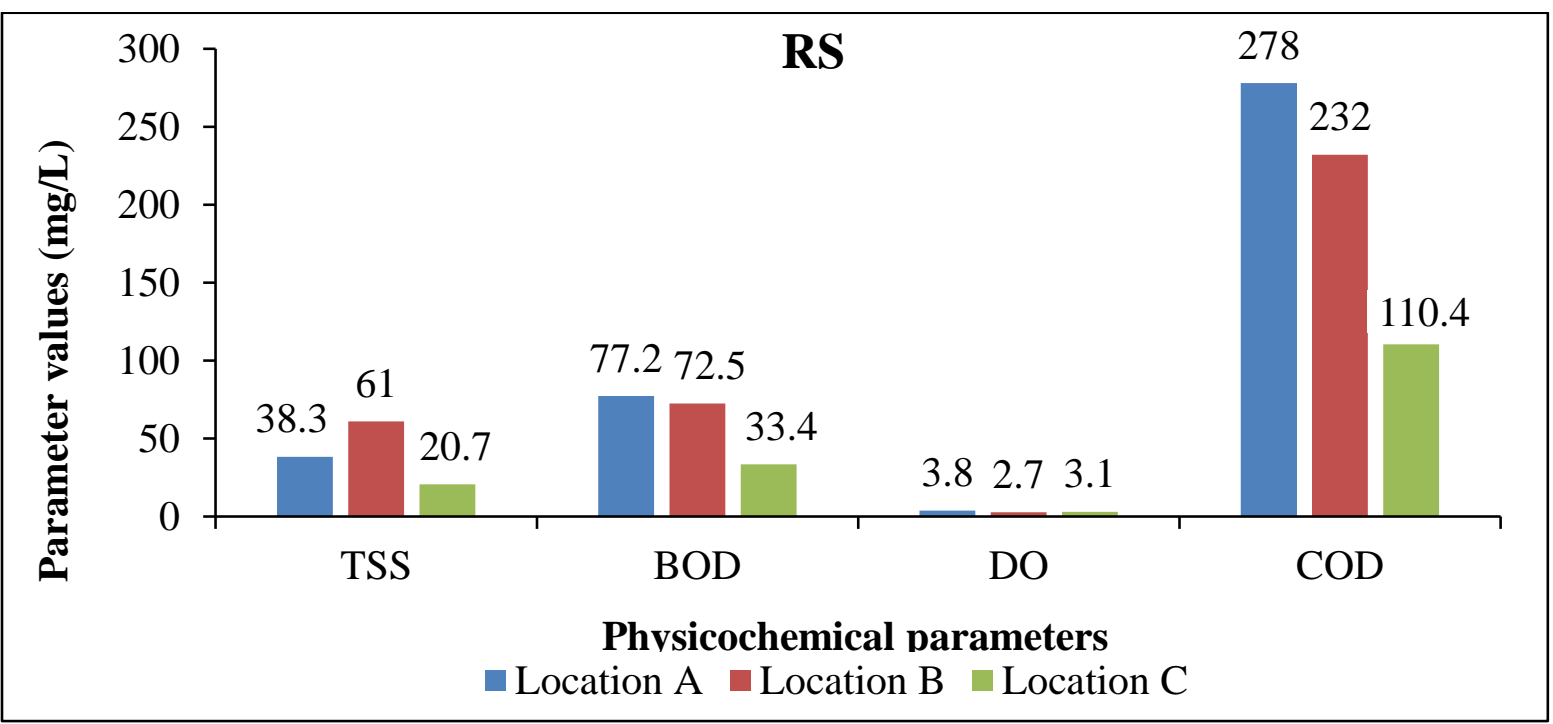


Figure 5: Physicochemical characteristics of effluent from semi-treated sewage (SS) at the different study locations.

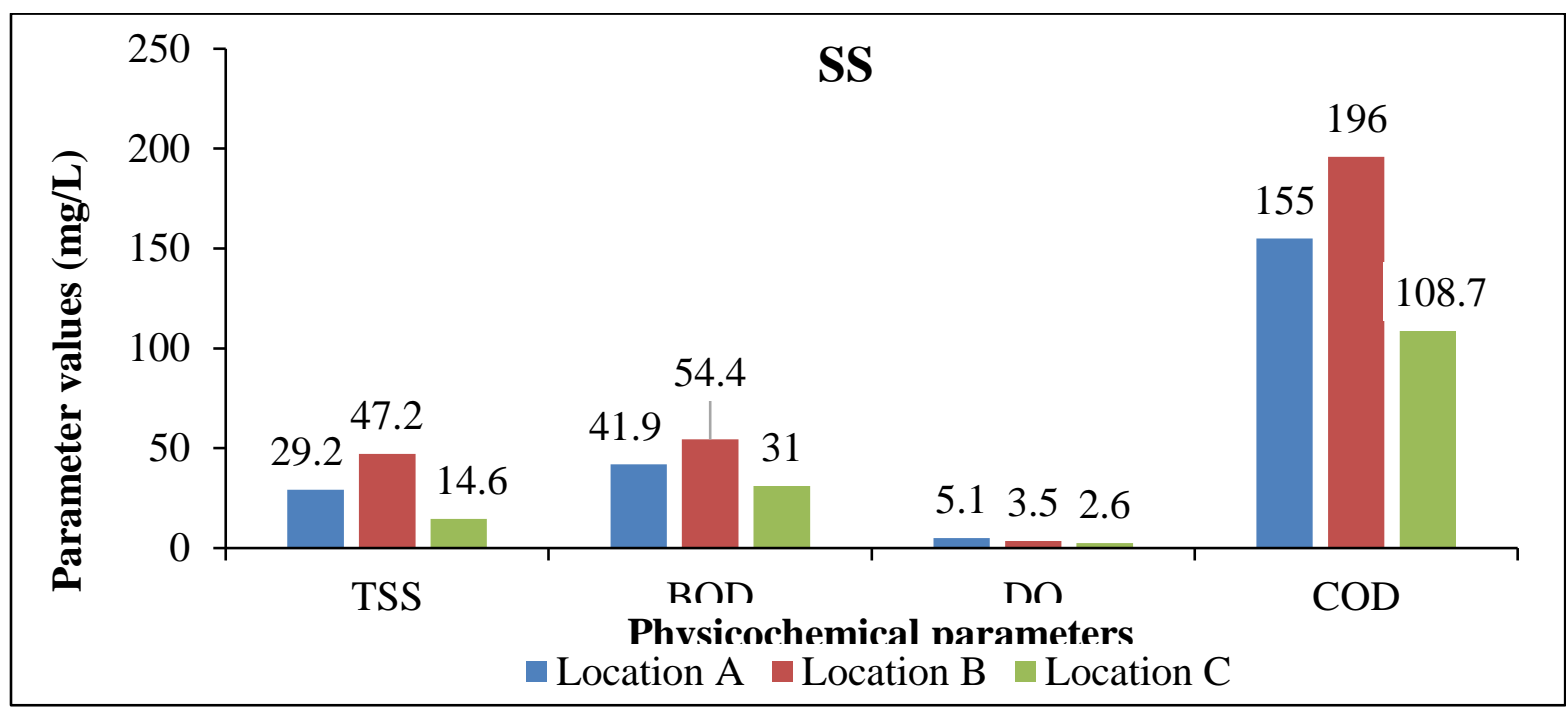

The total suspended solids (TSS) is the amount of particulate matter that remains suspended in a sample of water that can be trapped by a filter for analysis using a filtration apparatus (Rossi et al., 2006; Shah et al., 2014; Ismail, 2019). TSS of the semi-treated sewage generally decreased in all three locations when compared to the TSS of the raw sewage. The mean total suspended solids (TSS) of the semi-treated sewage (SS) samples (Figure 5) from all three locations studied ranged from (14.6 \pm $0.2-29.2 \pm 0.2 \mathrm{mg} / \mathrm{L})$ and $(20.7 \pm 0.2-61.0 \pm 11$ $\mathrm{mg} / \mathrm{L}$ ) for the raw sewage (RS) sample (Figure 4). The differences could be ascribed to the presence of more organic matter in the RS above those of the SS. Besides, the retention time of the RS in the inlet chamber before the sewage was then moved into the outlet chamber of the septic tank may have resulted in more solute digestion and percolation under the effect of gravity.

\section{Biological Oxygen Demand (BOD)}

The mean values of biological oxygen demand $\left(\mathrm{BOD}_{5}\right)$ decreased significantly at $(\mathrm{p}>0.05)$ in the semi-treated sewage (SS) compared to those of the raw sewage (RS) samples in all three sample areas studied (Figure 4\&5). Implying that biodegradation significantly took place in the septic tank systems in the study area. Location A had the highest $\mathrm{BOD}_{5}$ value $(77.2 \pm 0.2 \mathrm{mg} / \mathrm{L})$ in $\mathrm{RS}$ while location $\mathrm{C}$ had the lowest $\mathrm{BOD}_{5}$ value $(33.4 \pm 0.2 \mathrm{mg} / \mathrm{L}) . \mathrm{BOD}_{5}$ values in $\mathrm{RS}$ ranged from $(33.4 \pm 0.2-77.2 \pm 0.2$ $\mathrm{mg} / \mathrm{L}$ ) (Figure 4), and $31.0 \pm 1.0-41.57 \pm 0.46$ $\mathrm{mg} / \mathrm{L}$ in the SS (Figure 5). The mean $\mathrm{BOD}_{5}$ for the RS and SS for the sampled septic tanks in the study area is 59.4 and $42.8 \mathrm{mg} / \mathrm{L}$ respectively. Giving a difference of $16.6 \mathrm{mg} / \mathrm{L}$, representing about $28.0 \%$. That is, approximately $30.0 \%$ biodegradation of organic matter took place in the RS. BOD is considered an index of the effectiveness of bacterial digestion. Nwambo and Kehinde (2013) had earlier reported that BOD is perhaps the most important index in measuring the strength (effectiveness) of a biodegradation process. This they attributed to the high microbial population present in wastewater which requires greater oxygen consumption to biodegrade.

\section{Dissolved Oxygen (DO)}

Dissolved oxygen is characteristically expected to be low in a sealed-off septic tank system laddened with organic matter and microbes. Dissolved oxygen (DO) mean values for RS was between 2.7 \pm 0.2 and $3.8 \pm 0.1 \mathrm{mg} / \mathrm{L}$ as against those of the SS which was between $2.6 \pm 0.4$ and $5.1 \pm 0.1 \mathrm{mg} / \mathrm{L}$; indicating a slight increase of $13.5 \%$ in DO values of the SS in all three sample areas (Figure $4 \& 5$ ). This translates to a decrease in organic matter content which arrived at the SS chamber having already undergone some biodegradation in the time it was retained in the RS chamber. Therefore, amounting to a net increase in dissolved oxygen in the SS chamber as indicated by the results reported. 
DO in the SS will be boosted by effluent from the kitchen and bathroom which directly drains into it besides the effluent coming from the RS chamber. The RS on the other hand has faeces and urine flushed into it directly from the toilet. Location C however showed no considerable variation in the mean values of both RS and SS at $p>0.05$. Due to the fact that oxygen utilization within the septic tank system was poor owing to the presence of main anaerobes and facultative anaerobes and perhaps, poor retention time.

\section{Chemical Oxygen Demand (COD)}

Chemical oxygen demand measures the amount of oxidizable organic matter present in wastewater which can be oxidized by chemical oxidants (Khalaf and Mohammed, 2019; Prambudy et al., 2019). The chemical oxygen demand (COD) of the RS sample ranged from $110.4 \pm 0.2-278 \pm 1.0 \mathrm{mg} / \mathrm{L}$ while those of the SS sample was between $108.8 \pm 0.1-$ $155 \pm 2.0 \mathrm{mg} / \mathrm{L}$ (Figure 4\&5). This represents approximately a $25.0 \%$ reduction in the COD values in SS, indicating yet again, a decrease in organic matter concentration at the SS chamber. Like BOD, COD can provide an indication of the effectiveness of the digestion process. A value of 0.3 was obtained for the ratio of BOD/COD for both RS and SS samples in this study. The BOD/COD ratio gives the level of biodegradability of a sewage sample (Hur et al., 2010; Cossu et al., 2012; Treatment plant operation, 2017). For untreated municipal waste, the value ranges between $0.3-0.8$ (Hur et al., 2010; Cossu et al., 2012; Treatment plant operation, 2017). A value of 0.3 means slowly biodegradable; whereas, values above 0.5 indicate that samples are easily biodegradable. Meanwhile, values less than 0.3 are considered nonbiodegradable and may require acclimated microorganisms (Hur et al., 2010; Cossu et al., 2012; Treatment plant operation, 2017). Going by the $0.3 \mathrm{BOD} / \mathrm{COD}$ value obtained in this study; therefore, the septic tank waste samples (RS and SS) were considered slowly biodegradable, implying that the waste samples may contain toxic components - including high salinity, and may require acclimated microorganisms.

\section{Turbidity}

Figure 6: Turbidity characteristics of effluent from raw sewage (RS) and semi-treated sewage (SS) at the different study locations.

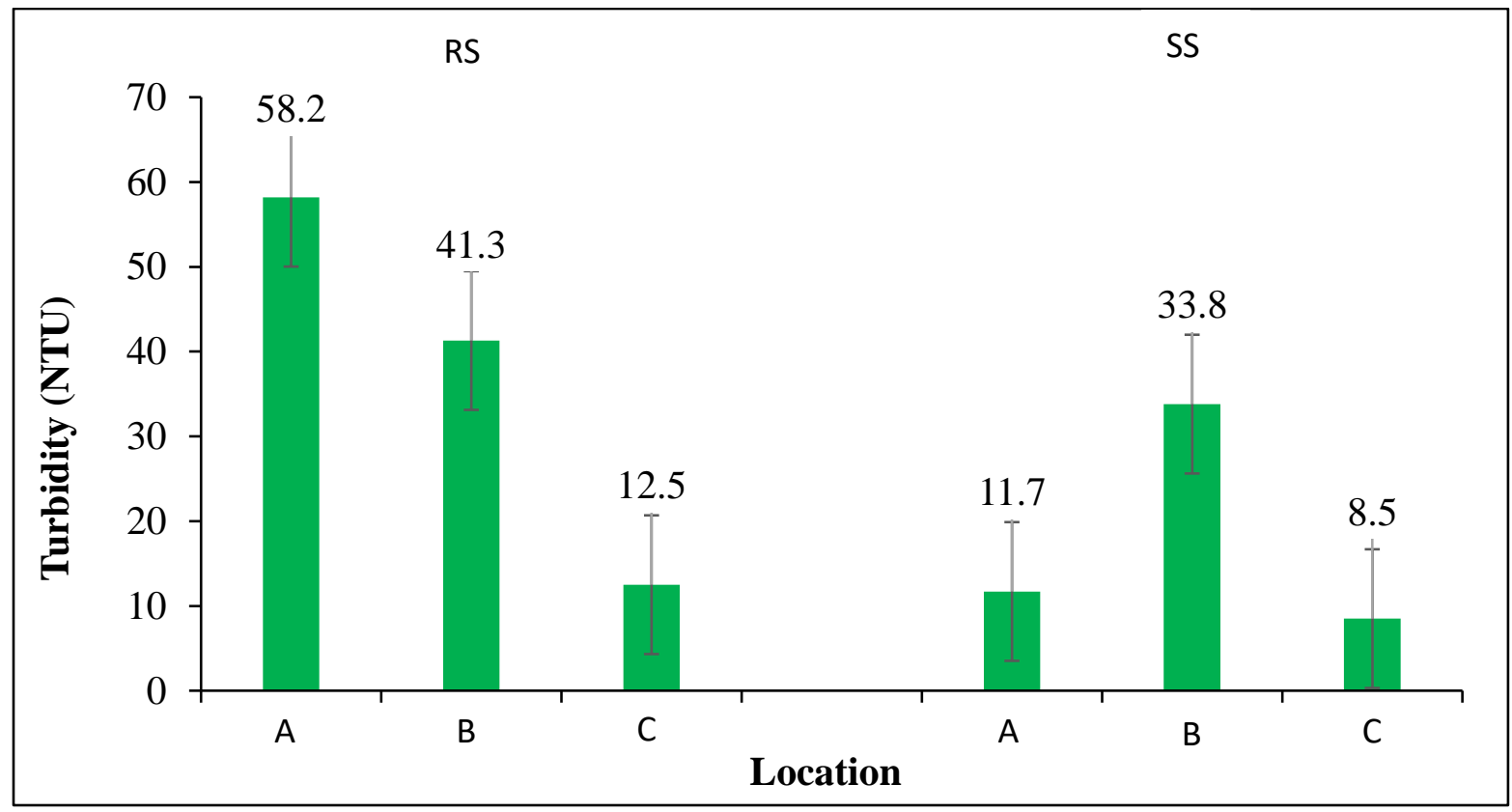

The results from figure 6 demonstrate that turbidity of effluent samples decreased along with locations as we moved from RS to SS (Figure 6). Location A had the highest turbidity of the raw sewage samples 
$(58.2 \pm 0.2 \mathrm{NTU})$ which decreased considerably in the SS (11.7 NTU). Fresh sewage normally has high turbidity and appears greyish. Turbidity relates to the amount of suspended chemical and biological particles in the water/wastewater sample (WHO, 2017). The least turbidity value was recorded at location C, with the RS having a value of 12.5 , and SS a value of $8.50 \mathrm{NTU}$. Turbidity values for RS and SS samples in location C are 41.3 and 38.8 NTU (Figure 6). An average person begins to see turbidity in water and waste/wastewater samples at around 5 NTU (Mohammed, 2015). Furthermore, a comparison of the differences in turbidity values of the RS and SS for each of the sample locations gives the following values: 46.5, 2.50, and 4.0 NTU for locations $\mathrm{A}, \mathrm{B}$, and $\mathrm{C}$ in that order. These values indicate that sample location $\mathrm{B}$ recorded the highest waste clarification (stabilization) since turbidity is expected to improve with increasing levels of microbial clarification. The values obtained for location A suggest little clarification. This infers that samples from these septic tanks may have poor retention times in the inlet chamber. Retention time is a key factor necessary to achieve the efficiency of biodegradation in septic tank systems (Boulds, 1997).

\section{Salinity}

Figure 7: Salinity characteristics of effluent from raw sewage (RS) and semi-treated sewage (SS) at the different study locations.

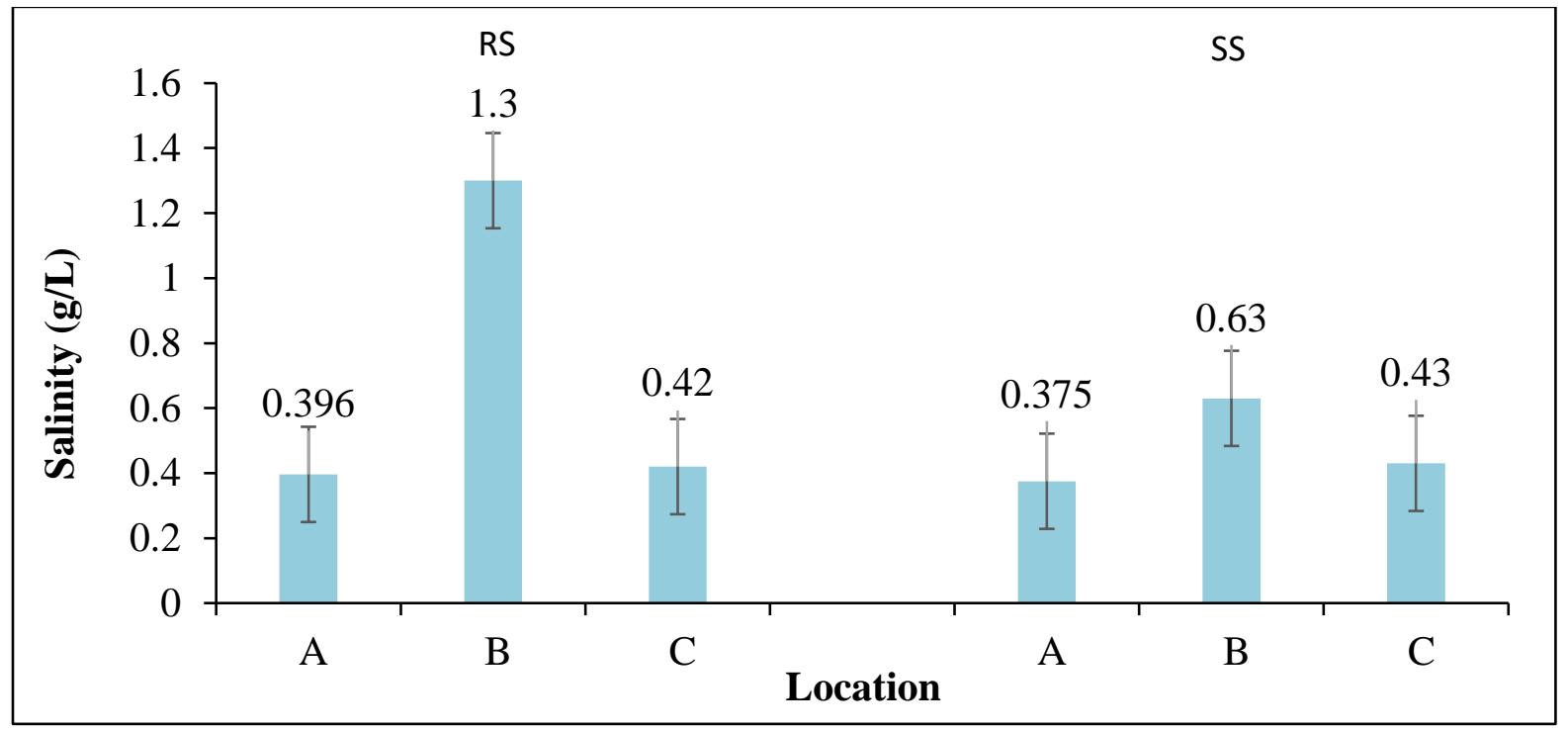

Salinity gives the concentration of dissolved salt in a given volume of water. It is expressed in $\mathrm{g} / 1000 \mathrm{~g}$ $(\mathrm{g} / \mathrm{kg}), \mathrm{g} / \mathrm{L}, \mathrm{mg} / \mathrm{L}$, and parts per thousand (ppt or $\%$ o). Water having salinity above $50 \mathrm{ppt}$ is considered a brine solution and is difficult for the survival of many microorganisms (Friedl, 2016). Results obtained in the study area (Figure 7) show that an average salinity value of $0.71 \mathrm{~g} / \mathrm{L}(710$ $\mathrm{mg} / \mathrm{L}$ ) was obtained in the RS of the study area, whereas, a value of $0.48 \mathrm{~g} / \mathrm{L}(480 \mathrm{mg} / \mathrm{L})$ was recorded as the average for the SS in the study area. $0.23 \mathrm{~g} / \mathrm{L}(230 \mathrm{mg} / \mathrm{L})$ is the margin of decrease in salinity between the RS and SS in the study area. Meanwhile, apart from location B, salinity remained relatively stable in both the RS and SS in the other two sample locations (Figure 7). Location B posted the highest salinity value of $1.3 \mathrm{~g} / \mathrm{L}(1300 \mathrm{mg} / \mathrm{L})$ in the RS sample and $0.63(630 \mathrm{mg} / \mathrm{L})$ in the SS. These are pointers to a high salt intake by inhabitants of the sample area which may pose some challenges to microbes in the septic tank system. Thus, painting a picture of septic tanks being a system of concentrated brine solutions. 


\section{Colour}

Figure 8: Colour characteristics of effluent from raw sewage (RS) and semi-treated sewage (SS) at the different study locations.

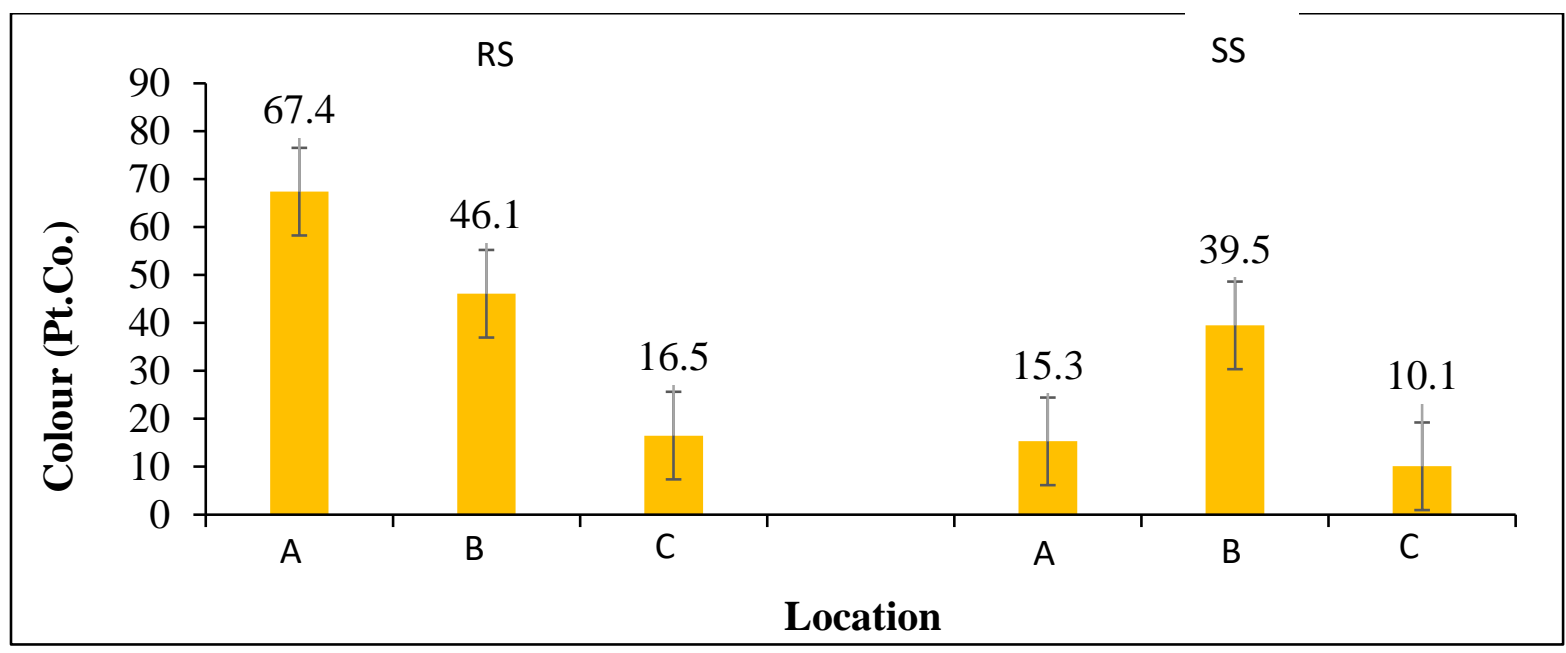

Platinum-Cobalt scale (Pt-Co) or the Alpha-Hazen scale are used to measure the levels of pollution in wastewater samples. The colour of wastewater is a measure of the presence of metals ions, organic acids, industrial waste, microbiological matter, and suspended particles (Masindi and Khathutshelo, 2018). In Figure 8, results of colour measurements of the effluents sewage (RS and SS) samples in the study area are displayed. These show colour values ranging from $16.5-67.4 \mathrm{Pt}-\mathrm{Co}$ in the $\mathrm{RS}$, and 10.1
- 39.5 Pt-Co in the SS. This implies that colour obviously decreased from RS to SS effluent chambers as the organic matter (suspended and dissolved) was biodegraded. Colour values were highest in location A but least in location $\mathrm{C}$ in the RS samples, however, in the SS samples, location B had the highest colour values (31.5 Pt-Co). Generally, the colours of the RS and SS effluents are blackish and greyish respectively as similarly reported by (Edokpayi et al., 2017).

\section{Nitrogen, Phosphorus, Ammonium Nitrogen, And Sulphate}

Figure 9: Chemical anionic characteristics of effluent from raw sewage (RS) at the different study locations.

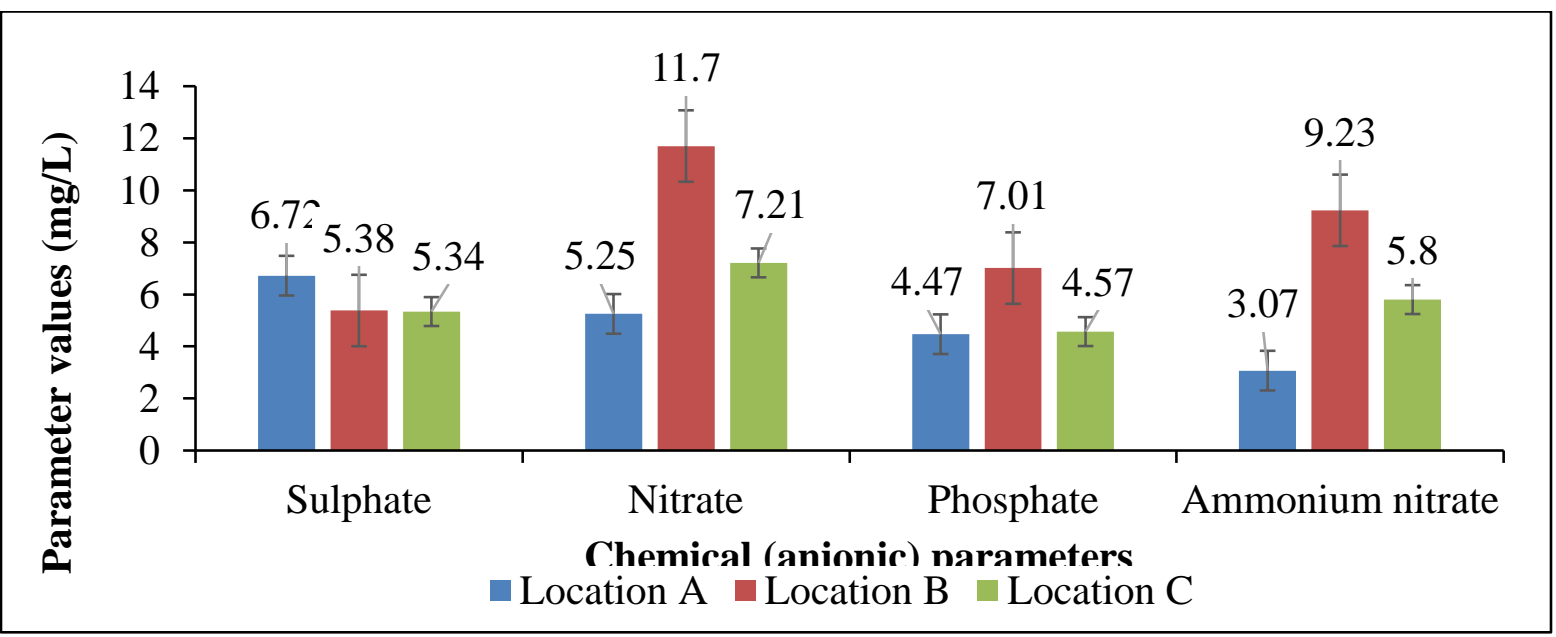


Figure 10: Chemical anionic characteristics of effluent from semi-treated sewage (SS) at the different study locations.

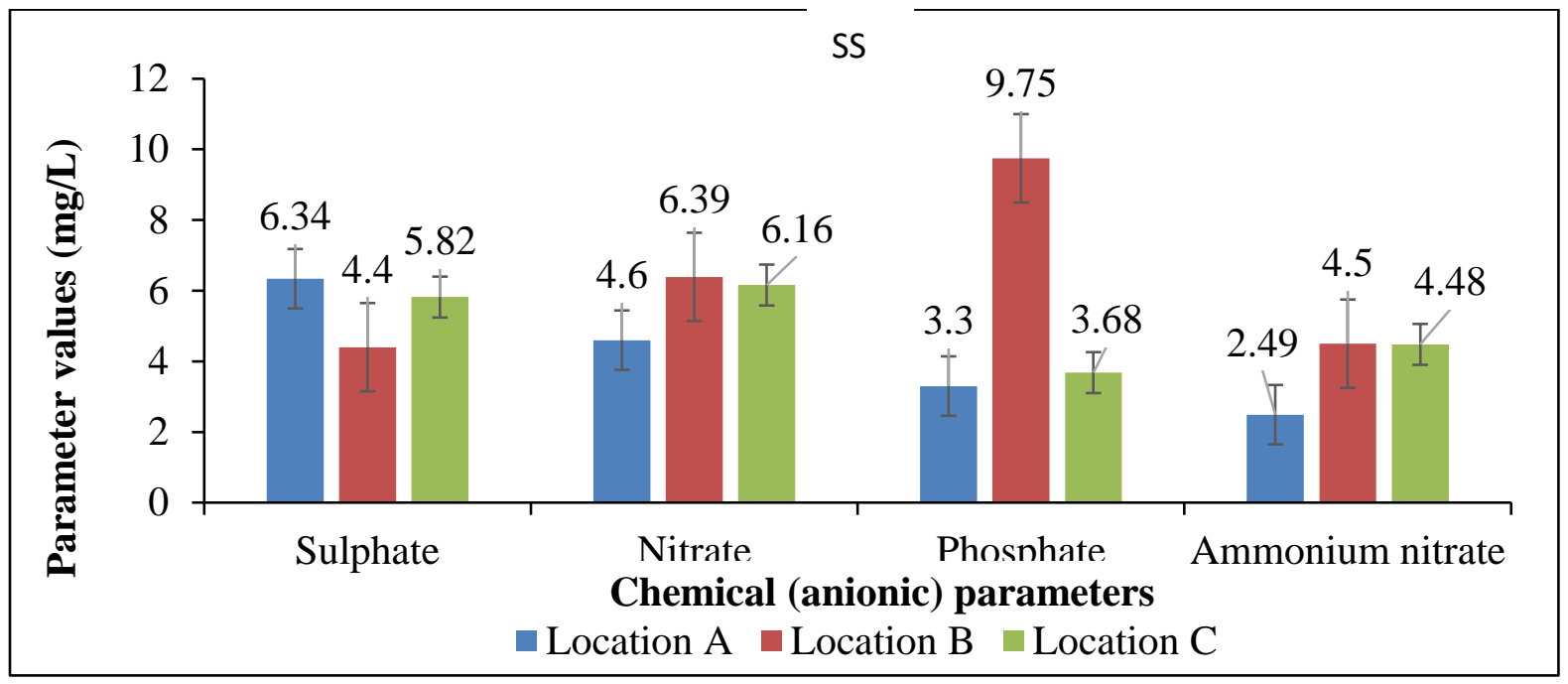

Nitrogen, phosphorus, ammonium nitrogen, and sulphate (sulfates) are nutrients required by plants and animals for growth and development (Lodish et al., 2000; WHO, 2000). Nitrogen, phosphorus, and sulphur elements are important components of nucleic acids, proteins, phospholipids, and hormones (Lodish et al., 2000; WHO, 2000). These elements are present in plant and animal food sources consumed by man, and in fertilizers. They find their way into septic tanks from excretory products of humans in the form of nitrates, phosphate, sulphate, and ammonium nitrogen. Their presence and concentration in the septic tank systems, therefore, can be traced to food consumption.

Nitrogen, phosphorus, sulphate, and ammonium nitrogen concentrations in effluent samples were highest in the raw sewage (RS) than in semi-treated sewage (SS) in all of the sample locations (figure $9 \& 10)$. The difference in these values can be ascribed to mineralization by microbes especially in the inlet chamber during the period of retention. Meanwhile, nitrates, phosphates, and ammonium nitrate were highest in Location B, recording values of $11.7,7.01$, and $9.23 \mathrm{mg} / \mathrm{L}$ respectively for the RS; $6.39,9.75$, and $4.50 \mathrm{mg} / \mathrm{L}$ for the SS followed in the order of magnitude by location $\mathrm{C}$. The implication of this result is that inhabitants of the sample location $\mathrm{B}$ had diets rich in protein sources by a large margin, followed by those in location $\mathrm{C}$ which showed a decrease in the levels of phosphorus and ammonium nitrogen in its raw sewage (RS) (7.01 \pm 0.01 and $4.57 \pm 0.47 \mathrm{mg} / \mathrm{L}$ ) for locations $B$ and $C$ respectively. A corresponding increase of $9.75 \pm$ 0.02 and $3.68 \pm 0.01 \mathrm{mg} / \mathrm{L}$ in the semi-treated sewage (SS) samples of these two locations were further observed. Effluents from kitchens contain food residues rich in phosphorus and nitrogen. Increased use of synthetic detergents also adds greatly to the phosphorus content of domestic sewage (Golconda, 2016) and may account for why there was an increase in the phosphorus levels in the SS chamber of location B from 7.01 to $9.75 \mathrm{mg} / \mathrm{L}$.

The trend is however different with sulphate levels of the effluents with sample locations. Sulphate values were highest in the RS and SS for samples collected in location A (Figure 9\&10). Sulphate values recorded in the RS samples were slightly decreased in the SS samples for all three locations. This can be attributed to the anaerobic decomposition of sulphates to sulphites (sulfites) and sulphides (sulfide) as some of the many byproducts. 
East African Journal of Health and Science, Volume 4, Issue 1, 2021

Article DOI: https://doi.org/10.37284/eajhs.4.1.469

Microbial Classification of Septic Tank Sewage

Table 1: Total Heterotrophic Bacteria (THB), Total Coliform Bacteria (TCB), and Total Fungal Count (TFC) of septic tank effluent samples (RS and SS) in the different locations

\begin{tabular}{|c|c|c|c|c|c|}
\hline \multicolumn{6}{|c|}{ Locations } \\
\hline $\mathbf{A}$ & & $\mathbf{B}$ & & $\bar{C}$ & \\
\hline RS & SS & RS & SS & RS & SS \\
\hline \multicolumn{6}{|c|}{ THB (105 cfu/mL) } \\
\hline $3.4 \pm 0.2$ & $3.0 \pm 0.2$ & $4.5 \pm 0.2$ & $3.8 \pm 0.1$ & $3.8 \pm 0.1$ & $4.0 \pm 0.2$ \\
\hline \multicolumn{6}{|c|}{ TCB (104 cfu/mL) } \\
\hline $4.0 \pm 0.2$ & $4.0 \pm 0.2$ & $5.1 \pm 0.1$ & $4.4 \pm 0.2$ & $3.6 \pm 0.2$ & $3.5 \pm 0.2$ \\
\hline \multicolumn{6}{|c|}{ TFC (104 cfu/mL) } \\
\hline $2.8 \pm 0.1$ & $2.1 \pm 0.1$ & $3.2 \pm 0.2$ & $3.3 \pm 0.2$ & $2.5 \pm 0.4$ & $2.7 \pm 0.2$ \\
\hline
\end{tabular}

The results of the total heterotrophic bacterial count (THB) studied in septic tank effluent in all three locations $\mathrm{A}, \mathrm{B}$ and $\mathrm{C}$ show that total heterotrophic bacteria count (THB) was highest in the raw sewage (RS) in two locations (B and C) except for location C $\left(3.8 \pm 0.1 \times 10^{5} \mathrm{cfu} / \mathrm{mL}\right)$ which showed a drop in the THB values (Table 1) as the organic matter become depleted.

In all, location $B$ had the highest THB count for raw sewage $\left(4.5 \pm 0.2 \times 10^{5} \mathrm{cfu} / \mathrm{ml}\right)$ while location A was the lowest, with a THB value of $3.4 \pm 0.2$ $\mathrm{x} 10^{5} \mathrm{cfu} / \mathrm{mL}$ in the effluent samples. It is, however, not unusual to sometimes observe decreases in bacterial counts in wastewater systems (Ademoroti, 1996b). This could be attributed to the presence of inhibitory chemicals (such as heavy metal ions, detergents, antiseptics, and "JIK" (solution of strong oxidizing bleaching agents), as well as high salinity in significant concentrations in domestic waste effluent that can affect microbial growth and hence require microbial re-acclimatization and repopulation to overcome the situation to achieve effective biodegradation of sewage.

Analysis of the Total Coliform Bacteria (TCB) revealed that location $B$ had the highest TCB count $\left(5.1 \pm 0.1 \times 10^{4} \mathrm{cfu} / \mathrm{mL}\right.$ and $\left.4.4 \pm 0.2 \times 10^{4} \mathrm{cfu} / \mathrm{mL}\right)$ of all the study locations in both RS and SS chambers respectively. High bacterial counts are directly correlated with the concentrations of organic matter normally as new cells are produced during metabolism. It is no surprise therefore for the bacteria count to be high with respect to location B going by the high nutrients proportions earlier reported for nitrogen, phosphorus, and sulphur (sulfur) in the previous section.
Bacterial isolates from wastewater samples included Staphylococcus aureus, Proteus mirabilis, Escherichia coli, Bacillus subtilis, Klebsiella sp., Micrococcus sp., Shigella sp., Salmonella sp., Enterobacter aerogenes, Streptococcus faecalis, Pseudomonas aeruginosa, and Aeromonas sp. (Table 2). 


\section{Table 2: Cultural, Morphological and Biochemical Characteristics of Bacterial isolates from septic tank sewage effluent}

\begin{tabular}{|c|c|c|c|c|c|c|c|c|c|c|c|c|}
\hline \multicolumn{13}{|c|}{ Bacterial Isolates } \\
\hline Characteristics & 1 & 2 & 3 & 4 & 5 & 6 & 7 & 8 & 9 & 10 & 11 & 12 \\
\hline Colony & Mucoid & Circular & Circular & Circular & Circular & Circular & $\begin{array}{l}\text { Circula } \\
\mathrm{r}\end{array}$ & Rhizoid & Circular & & Circular & Dome \\
\hline Pigmentation & Greenish & Creamy & Circular & Orange & Creamy & $\begin{array}{l}\text { Light } \\
\text { yellow }\end{array}$ & Creamy & $\begin{array}{l}\text { Circular } \\
\text { white }\end{array}$ & $\begin{array}{l}\text { Creamy } \\
\text { brown }\end{array}$ & $\begin{array}{l}\text { Whit } \\
\text { e }\end{array}$ & Pale & White \\
\hline Gram reaction & - & - & - & + & - & + & - & + & & + & - & - \\
\hline Cell type & Rod & Short rod & Rod & Cocci & Rod & Cocci & Rod & Rod & Rod & $\begin{array}{l}\text { Cocc } \\
\mathrm{i} \\
\end{array}$ & Rod & Rod \\
\hline Mobility & + & + & + & - & - & - & & + & + & - & - & + \\
\hline Spore stain & - & - & & - & - & - & - & + & - & - & - & - \\
\hline \multicolumn{13}{|l|}{$\begin{array}{l}\text { Biochemical } \\
\text { Test }\end{array}$} \\
\hline Catalase & + & + & & + & + & + & + & + & - & - & + & + \\
\hline Oxidase & + & - & + & - & - & - & - & + & + & & - & - \\
\hline Indole & - & - & - & - & - & - & + & - & - & & + & - \\
\hline Voges Proskaur & - & + & + & - & + & & - & - & + & - & + & - \\
\hline Methyl Red & - & - & + & - & + & & + & + & & + & - & + \\
\hline $\begin{array}{l}\text { Citrate } \\
\text { Utilization }\end{array}$ & + & + & + & + & + & & - & - & - & & - & + \\
\hline Urase & + & + & + & - & + & - & - & + & - & & - & - \\
\hline Lactose & - & $\mathrm{A}$ & - & - & - & & $\mathrm{A}$ & $\mathrm{AG}$ & $\mathrm{A}$ & & $\mathrm{AG}$ & - \\
\hline Glucose & $\mathrm{A}$ & $\mathrm{AG}$ & $\mathrm{G}$ & & $\mathrm{AG}$ & + & A & & $\mathrm{AG}$ & A & A & $\mathrm{AG}$ \\
\hline Sucrose & - & + & + & $\mathrm{A}$ & + & & $\mathrm{A}$ & - & $\mathrm{A}$ & & $\mathrm{A}$ & - \\
\hline Mannitol & $\mathrm{A}$ & + & - & $\mathrm{A}$ & + & & $\mathrm{A}$ & - & - & $\mathrm{A}$ & $\mathrm{AG}$ & A \\
\hline $\begin{array}{l}\text { Possible } \\
\text { identity } \\
\text { isolates }\end{array}$ & $\begin{array}{l}\text { Pseudom } \\
\text { onas sp. }\end{array}$ & $\begin{array}{l}E . \\
\text { aerogene } \\
s\end{array}$ & $\begin{array}{l}\text { Proteus } \\
\text { mirabili } \\
s\end{array}$ & $\begin{array}{l}\text { Micrococc } \\
\text { us sp. }\end{array}$ & $\begin{array}{l}\text { Klebsiell } \\
a \mathrm{sp} .\end{array}$ & $\begin{array}{l}\text { Staphyloco } \\
\text { ccus sp. }\end{array}$ & E. coli & $\begin{array}{l}\text { Bacillus } \\
\text { sp. }\end{array}$ & $\begin{array}{l}\text { Aeromona } \\
s \mathrm{sp} .\end{array}$ & $\begin{array}{l}\text { E. } \\
\text { faeca } \\
\text { lis }\end{array}$ & Shigella & $\begin{array}{l}\text { Salmonell } \\
a \text { sp. }\end{array}$ \\
\hline
\end{tabular}

$* A=$ Acid,$G=$ Gas 
Again, a high total fungal count (TFC) was similarly observed in the RS and SS samples of location B. The trend in the THC values recorded for the RS and SS samples in locations A, B and C are varied and inconsistent. Fungal counts seemed to increase in the SS chamber except in location A. This variation cannot be immediately accounted for or explained. Fungal isolates from both raw and semi-treated sewage samples included: Aspergillus niger, Mucor mисеdo, Penicillium sp., Geotrichum albidum, Fusarium sp., and Candida sp. (Table 3). The THB, TCB, and TFC of effluent samples showed on average no significant difference between raw and semi-treated sewage samples, thus supporting the view that septic tank sewage treatment does not completely accomplish microbial removal (Tchobanoglous et al., 2003).

Table 3: Characteristics of fungal isolate from septic tank sewage effluent

\begin{tabular}{|c|c|c|c|c|c|c|}
\hline Character & F1 & $\mathrm{F} 2$ & F3 & F4 & F5 & F6 \\
\hline \multicolumn{7}{|c|}{ Macroscopic } \\
\hline $\begin{array}{l}\text { Growth } \\
\text { form }\end{array}$ & $\begin{array}{l}\text { Velvety to } \\
\text { flaky }\end{array}$ & $\begin{array}{l}\text { Powdery to } \\
\text { velvety } \\
\text { surface }\end{array}$ & $\begin{array}{l}\text { Wooly network } \\
\text { of hyphae with } \\
\text { root like } \\
\text { rhizoids }\end{array}$ & $\begin{array}{l}\text { Wooly fibre } \\
\text { with compact } \\
\text { network } \\
\text { hyphae }\end{array}$ & $\begin{array}{l}\text { Large circular } \\
\text { colonies }\end{array}$ & $\begin{array}{l}\text { Mycelium } \\
\text { fragment } \\
\text { easily with } \\
\text { inoculation } \\
\text { with needle }\end{array}$ \\
\hline Colour & Yellow & $\begin{array}{l}\text { Light green to } \\
\text { white border }\end{array}$ & $\begin{array}{l}\text { Initially white, } \\
\text { later grey with } \\
\text { dots }\end{array}$ & $\begin{array}{l}\text { White with red } \\
\text { pigment at the } \\
\text { bottom on PDA }\end{array}$ & Creamy & White \\
\hline \multicolumn{7}{|c|}{ Microscopic } \\
\hline Hyphae & Septate & Septate & $\begin{array}{l}\text { Thick non- } \\
\text { septate }\end{array}$ & $\begin{array}{l}\text { Sickle shaped } \\
\text { septate conidia }\end{array}$ & Pseudomycelium & $\begin{array}{l}\text { Septate with } \\
\text { dichotomous } \\
\text { ramifications }\end{array}$ \\
\hline Spores & $\begin{array}{l}\text { Non- } \\
\text { septate } \\
\text { Candidia }\end{array}$ & $\begin{array}{l}\text { Candidia } \\
\text { borne in } \\
\text { Conidiophore }\end{array}$ & Sporangiophore & $\begin{array}{l}\text { Sickle shaped } \\
\text { septate conidia }\end{array}$ & $\begin{array}{l}\text { Short chains oval } \\
\text { or elongated }\end{array}$ & $\begin{array}{l}\text { Pronounced } \\
\text { anthrospores }\end{array}$ \\
\hline $\begin{array}{l}\text { Possible } \\
\text { Identity }\end{array}$ & $\begin{array}{l}\text { Aspergillus } \\
\text { niger }\end{array}$ & $\begin{array}{l}\text { Penicillium } \\
\text { sp. }\end{array}$ & Mисог тисеdo & Fuscarium sp. & Candida sp. & $\begin{array}{l}\text { Geotrichum } \\
\text { albidum }\end{array}$ \\
\hline
\end{tabular}

\section{Soil Analyses of The Study Area}

Figure 11: Analyses of the soil types and characteristics of the three sample areas: Locations A, B and $\mathbf{C}$.

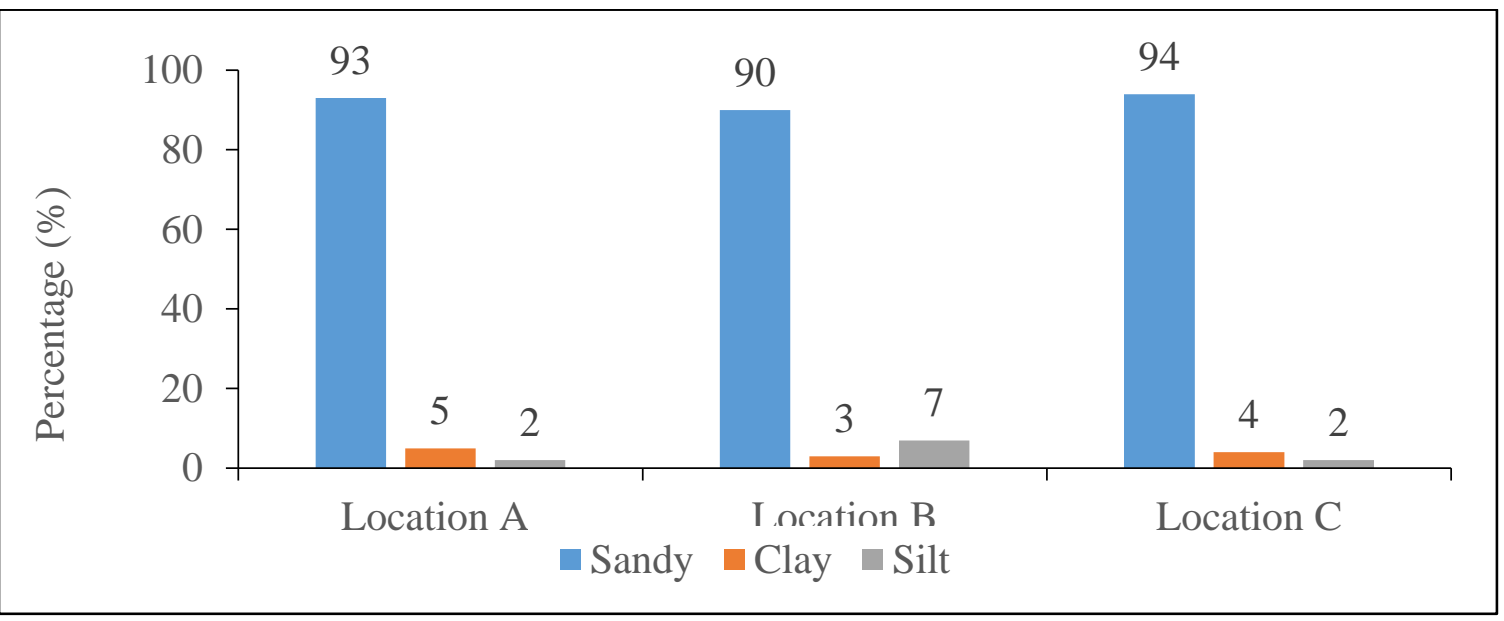


Analyses of the soil types and characteristics of the three sample areas were undertaken to establish the soil properties of the study area and to establish a connection with a hydraulic conductivity of effluent and retention time, so as to arrive at a perspective of the impact of soil types on the study. Figure 11 are bar charts of the soil components of the sample area representing Agbor, Benin, and Sapele communities respectively. The soil is comprised of sandy, clayey, and silt components with the sandy component being predominant, with clay the second larger component, and silts the least.

According to the results of the soil analyses, it is obvious the soil types of the three sample areas are similar in any respect. They were all composed of soil components in nearly the same proportions. However, the percentage composition of each of these components varied slightly from location to location (Figure 11).

The sample taken from Benin City (Edo State) location A recorded the highest clay soil component of the three locations. Clay soil is noted for its water retention capacity thereby negating hydraulic conductivity by offering significant resistance to seepage. Silt gives an idea of the amount of organic matter inherent in the soil of the area. These notwithstanding, the proportion of the sandy soil in the sampled areas more than overwhelmed the combined proportions of the clay and silt components (Figure 11). This exacerbates the hydraulic conductivity of nutrients and pollutants through the soil to nearby wells (characterized by eutrophication) and into groundwater aquifers. Hence, we can conclude that the soil of these sample areas is invariably the same and offers a similar contribution to the dynamics of septic tank effluents in the study area.

\section{CONCLUSION}

The use of septic tank sewage systems is an agelong practice that has gained more and more relevance in recent years due to its affordability and ease of use. For the system to perform optimally, its operation, utilization techniques, and soil types must be well studied. This research endeavour sought to determine the physicochemical $(\mathrm{pH}$, turbidity, electrical conductivity, dissolved oxygen, biological oxygen demand, total suspended solids, nitrates, and phosphate) and microbial qualities of both the inlet and outlet chambers effluent from individual septic tanks within the three different localities under review. These were done in order to ascertain the level of clean-up done by the septic tank in these communities and to address the unfortunate incidences of failure observed. The work surmised that significant bacteria and organic matter removal was not accomplished in the septic tank.

The results of the physicochemical parameters $(\mathrm{pH}$, EC, TSS, BOD, DO, and COD) and the microbial analyses (THB, TCB, and TFC) of the septic tank effluent samples show that raw sewage (RS) samples were only slightly but not significantly higher than those of the semi-treated (SS) samples, indicative of the fact that not much biodegradation occurred in the inlet chamber of the septic tank system. Thus, again demonstrating that septic tanks do not completely accomplish bacteria and organic matter remediation. Therefore, septic tank effluent cannot be considered safe.

From the $\mathrm{BOD}_{5} / \mathrm{COD}$ value of 0.30 biodegradability index and the $53.0 \%$ methanogen proportion of the microbial diversity obtained in the study area (Oyem et al., 2020), together with the rather low THB, TCB, and TFC counts (in the order of $10^{4}$ and $10^{5} \mathrm{cfu} / \mathrm{ml}$ ), we can conclude that the seemingly poor performance of the septic tank system could be associated with overloading and presence of noxious materials (including high saline conditions) which are deleterious to the microbial community. To ameliorate these factors, a situation that allows for a significant increase in the retention time of the inlet chamber, that is, larger RS chambers is recommended. Reacclimatized and increased bacterial population or consortia may be needed to achieve better biodegradation potential and efficiency of the septic tank system. Soil analysis confirmed that the soil was predominantly sandy and translated to high hydraulic conductivity in the soakaway pits (SS chamber). Also, the ratio of the number of household inhabitants to a septic tank needs to be reconsidered.

\section{ACKNOWLEDGEMENT}

The authors wish to thank Professor R. O. Onyeonwu and the staff of Martlet Environmental 
Research Laboratory Limited, Benin City, Edo State for assistance with the analyses. We also thank Mr. Saturday (the Plumber) for his invaluable assistance with sample collection and sealing off septic tanks afterward.

\section{FUNDING}

This research did not receive any funding from funding agencies in the public, commercial, or notfor-profit sector.

\section{REFERENCES}

Abdussalam, A. F. (2015). Changes in indices of daily temperature and precipitation extremes in northwest Nigeria. Science World Journal, 10(2), 18-26.

Adams, V. D. (1990). Waste Water Examination Manual. Lewis Publishers Inc. Chelsea, Michigan.

Ademoroti, C. M. A. (1996). Standard methods for water and effluents analysis.

Ademoroti, Christopher M. A. (1996b). Environmental Chemistry and Toxicology (First). Ibadan: Foludex Press.

Angeli, J. B., Morales, A., LeFloc'h, T., Lakel, A., \& Andres, Y. (2018). Anaerobic digestion and integration at urban scale: feedback and comparative case study. Energy, Sustainability and Society, 8(1), 1-23.

APHA. (1992). Standard Methods for the Examination of Water and Waste Water (18th ed.). Washington, DC: Association, American Public Health.

APHA. (1995). Standard Methods for the Examination of Water and Waste Water (20th ed.). Washington, DC: American Public Health Association.

ASTM. (1995). Water and Environmental Technology, American Standard Testing Method $1 \& 2$.

Avwunudiogba, A. (2000). A comparative analysis of soil and nutrient losses on maize plots with different tillage pratices in the Ikpoba river basin of south-western Nigeria. The Nigerian Geographical Journal, 3, 199-208.

Bitton, G. (1999). Waste Water Microbiology (2nd ed.). New York: Wineglass.

Boulds, M. S. (1997). Design and Performance of Septic Tanks. In Site Characterization and Design of Onsite Septic Systems ASTM STP 901, In J. S. E. Bedinger, M. S., Johnson, A. I., and Fleming (Ed.), American Society for Testing Materials. Philadelphia, Pennsylvania, USA.

Burubai, W. (2005). Source Water Pollution abatement and best management practices. In 7 th African USA International Conference on Manufacturing Technology. (pp. 277-282). Port Harcourt.

Cossu, R., Lai, T., \& Sandon, A. (2012). Standardization of BOD5/COD ratio as a biological stability index for MSW. Waste management, 32(8), 1503-1508.

Doelle, H. W. (2001). Biotechnology and human development in developing countries. Electronic Journal of Biotechnology, 4(3), 17-18.

Edokpayi, J. N., Odiyo, J. O., \& Durowoju, O. S. (2017). Impact of wastewater on surface water quality in developing countries: a case study of South Africa. Water quality, 401-416.

Eresanya, E. O., Ajayi, V. O., Daramola, M. T., \& Balogun, R. (2018). Temperature extremes over selected stations in Nigeria. Physical Science International Journal, 1-10.

Fidelia, N. In Burubai, et al. (2004). An evaluation of septic tank performance in Bayelsa State, Nigeria. Agricultural Engineering International. The CIGR Ejournal. Manuscript BC 06 009. 9.

Fondriest Environmental. (2013). Inc. $\mathrm{pH}$ of Water. Fundamentals of Environmental Measurements, 19.

Friedl, S. (2016). What is Salinity?-Definition \& Effects. Retrieved July 17, 2020, from https://study.com/academy/lesson/what-issalinity-definition-effects-quiz.html 
Golconda, A. Z. (2016). Characteristics of sewage and treatment required. https://www.researchgate.net/profile/ZafarGolconda/publication/292407057_CHARACTE RISTICS_OF_SEWAGE_AND_TREATMEN T_REQUIRED/links/56ae59d208aeaa696f2eab 7d/CHARACTERISTICS-OF-SEWAGE-ANDTREATMENT-REQUIRED.pdf

Hur, J., Lee, B. M., Lee, T. H., \& Park, D. H. (2010). Estimation of biological oxygen demand and chemical oxygen demand for combined sewer systems using synchronous fluorescence spectra. Sensors, 10(4), 2460-2471.

Ismail, A. F. (2019). Membrane Fouling. In Reverse Osmosis (First, pp. 189-220). Elsevier.

Abdulla, H., K Bashar Al-Quraeshi, N., Nabeeh, F., \& Al-Awadi, J. (2012). Study of Chemical Oxygen Demand (COD) in Relation to Biochemical Oxygen Demand (BOD). journal of kerbala university, 8(1), 40-43.

Lodish, H., Berk, A., Zipursky, S. L., et al. (2000). Structure of Nucleic Acids. In Molecular Cell Biology. (4th ed.). New York: W. H. Freeman.

Masindi, V. \& Khathutshelo, L. M. (2018). Environmental Contamination by Heavy Metals. In R. F. Saleh, H. E-D. M., and Aglan (Ed.), Heavy Metals (pp. 115-133). InterOpen.

Meegoda, J. N., Li, B., Patel, K., \& Wang, L. B. (2018). A review of the processes, parameters, and optimization of anaerobic digestion. International journal of environmental research and public health, 15(10), 2224.

Mohammed, S. S. (2015). Effect of $\mathrm{pH}$ on the Turbidity Removal of Wastewater. Open Access Library Journal, 2(12), 1.

Nwambo, Y. P., \& Kehinde, A. J. (2013). Sewage and detergent degrading microorganisms in septic tank system. International Journal of Application or Innovation in Engineering \& Management, 2(5).

Odjugo, P. A. O. (2008). The effect of tillage systems and mulching on soil microclimate, growth and yield of yellow yam (Dioscorea cayenensis) in Midwestern Nigeria. African Journal of Biotechnology, 7(24).

Ogunrayi, O. A., Akinseye, F. M., Goldberg, V., \& Bernhofer, C. (2016). Descriptive analysis of rainfall and temperature trends over Akure, Nigeria. Journal of Geography and Regional Planning, 9(11), 195-202.

Oyem, H. H., Oyem, I. M., \& Ezeweali, D. (2014). Temperature, $\mathrm{pH}$, electrical conductivity, total dissolved solids and chemical oxygen demand of groundwater in Boji-BojiAgbor/Owa area and immediate suburbs. Research Journal of Environmental Sciences, 8(8), 444.

Oyem, I. M., Oyem, H. H., Oyem, M. N., Usese, A. I., Ezenwali, D., \& Obiwulu, E. N. O. (2015). An Investigation in to Groundwater Contaminations in Agbor and Owa Communities in Nigeria. Sacha Journal of Environmental Studies, 5, 28-35.

Pepper, I. \& Gerba, C. P. (2004). Environmental Microbiology (Second). San Diego, Claifornia: Elsevier Academic Press.

Prambudy, H., Supriyatin, T., \& Setiawan, F. (2019, October). The testing of chemical oxygen demand (COD) and biological oxygen demand (BOD) of river water in cipager cirebon. In Journal of Physics: Conference Series (Vol. 1360, No. 1, p. 012010). IOP Publishing.

Robert, W., \& Terry, B. (2004). Septic tank operations. National Decentralized water Resources Capacity Development Project, Washington.

Rojer, R. N. (2002). Introduction to Environmental Analysis. New York: John Wiley \& Sons.

Rossi, L., Fankhauser, R., \& Chevre, N. (2006). Water quality criteria for total suspended solids (TSS) in urban wet-weather discharges. Water Science and Technology, 54(6-7), 355-362.

Shah, S. M. H., Yusof, K. W., Mustafa, Z., and Hashim, A. M. (2014). Concentration of total suspended solids (TSS) influenced by the simulated rainfall event on highway embarkment. International Journal of Environmental Toxicology, 6, 747. 
Stuth, B. and Guichard, M. (1989). Managing grease and oil in restaurant waste. In Proceedings of the sixth North-West onsite waste water treatment short course, College of Engineering, University of Washington, Seattle, WA. (pp. 380-395.). Seattle, WA.

Tchobanoglous, G., Burton, F.L. and Stensed, H. D. (2003). Waste Water Engineering (Treatment Disposal Reuse (4th ed.). Metcalf and Eddy Inc, McGraw-Hill Book Company.

WHO. (2000). Nutrition for health and development: a global agenda for combating malnutrition (No. WHO/NHD/00.6). World Health Organization.

WHO. (2017). Guidelines for drinking-water quality. World Health Organization.

Yilmaz, E., \& Koç, C. (2014). Physically and chemically evaluation for the water quality criteria in a farm on Akcay. Journal of Water Resource and Protection, 2014. 